\title{
Reed-Sternberg/lymphocyte rosette: lymphocyte subpopulations as defined by monoclonal antibodies
}

\author{
CHRISTINE S MORRIS, ${ }^{*}$ AE STUART $\dagger$ \\ From the University of Newcastle upon Tyne, Department of Pathology, Royal Victoria Infirmary, Newcastle \\ upon Type NE1 4LP
}

SUMMARY The Reed-Sternberg cell/lymphocyte rosette characteristic of Hodgkin's disease tissue and cell suspensions was investigated with monoclonal antibodies on fresh viable cell suspensions prepared from nine cases of Hodgkin's disease. The biopsy material comprised six spleens and three lymph nodes. The majority of the rosetting lymphocytes were $T$ cells, primarily of the helper subset. Some of the attached lymphocytes were suppressor $\mathrm{T}$ cells. In addition, a few of the rosetting lymphocytes around Reed-Sternberg cells were B cells.

A characteristic finding in Hodgkin's disease tissue or cell suspensions is the lymphocyte rosette around the Reed-Sternberg cells. It was during the investigation of $T$ cell functions in Hodgkin's disease and the relation of the transformed lymphocyte to the Reed-Sternberg cell that this phenomenon of lymphocyte rosetting around Reed-Sternberg cells was first discovered. Dorfman et al' noted the interaction of lymphocytes and Reed-Sternberg cells and that their cytoplasm was juxtaposed and interdigitated. Other workers ${ }^{23}$ observed the tightness of lymphocyte apposition to Reed-Sternberg cells and suggested that this close apposition of active lymphocytes may correlate with patient survival. Several authors ${ }^{4-7}$ have reported that the majority of attached lymphocytes around Reed-Sternberg cells are $T$ cells. This was also confirmed during a recent study $^{8}$ using the $\mathrm{E}$ rosette technique, a heterologous anti-T cell serum, and the OKT (anti-T cell) series of monoclonal antibodies. The latter investigation also indicated, however, that a few of the rosetting lymphocytes were B cells. In this respect it is of interest that Curran and Jones ${ }^{9}$ also noted that Reed-Sternberg cells were associated with $\mathrm{S} \mathrm{Ig}^{-}$and $\mathrm{S} \mathrm{Ig}^{+}$lymphocytes. As well as the anti- $\mathrm{T}$ cell antisera, an heterologous anti-B cell serum and several

\footnotetext{
*Present address: Department of Neurosurgery. The Midland Centre for Neurosurgery and Neurology, Smethwick, Warley, West Midlands.

$†$ Present address: Department of Pathology, (32), King Khalid University Hospital, PO Box 2925, Riyadh 11461, Saudi Arabia.
}

Accepted for publication 24 April 1984
anti-Ia (anti-HLA DR) monoclonal antibodies were used in this study, in addition to OKM1, an antimonocyte/null cell/granulocyte monoclonal antibody. Indirect immunofluorescence was used throughout the investigation on viable cell suspensions made from fresh involved Hodgkin's disease lymph nodes and spleens.

\section{Material and methods}

\section{HETEROLOGOUS ANTISERA}

The preparation of the anti-B and anti- $\mathrm{T}$ cell sera have been reported previously. ${ }^{10} 11$

\section{PREPARATION OF HODGKIN'S DISEASE TISSUE SUSPENSIONS}

Fresh involved lymph nodes and spleens, all containing characteristic Reed-Sternberg cells, were obtained from nine adult patients with Hodgkin's disease. The biopsy material comprised six spleens and three lymph nodes from different patients and types of Hodgkin's disease (Table 1). The tissue was minced finely in Hanks' basal salt solution (HBSS, Gibco-Europe) and passed through needles of decreasing size to produce an homogeneous and well dissociated cell suspension. The cells were washed twice in HBSS and finally resuspended at 5 $\times 10 \% \mathrm{ml}$ in RPMI 1640 , supplemented with $5 \%$ fetal calf serum (both from Gibco-Europe). Spleen suspensions were prepared similarly after separation on Ficoll-Paque (Pharmacia).

MONOCLONAL ANTISERA

The OKT series of anti- $T$ cell monoclonal anti- 
Table 1 Reactivity of lymphocytes attached to Reed-Sternberg cells, with anti-Ia, anti-T cell and OKMI monoclonal antibodies

\begin{tabular}{|c|c|c|c|c|c|c|c|c|c|}
\hline \multirow[t]{2}{*}{ Case no } & \multirow[t]{2}{*}{ Biopsy } & \multirow{2}{*}{$\begin{array}{l}\text { Hodgkin's } \\
\text { disease } \\
\text { type }\end{array}$} & \multicolumn{7}{|c|}{ Monoclonal antibodies } \\
\hline & & & $\alpha-I a$ & $C A 206^{*}$ & $D A 6.231^{*}$ & $O K T 3 \ddagger$ & $O K T 4 \ddagger$ & $O K T 8 \ddagger$ & $\mathrm{OKMI}^{\dagger}$ \\
\hline $\begin{array}{l}1 \\
2 \\
3 \\
4 \\
5 \\
6 \\
7 \\
8 \\
9\end{array}$ & $\begin{array}{l}\text { Spl } \\
\text { LN } \\
\text { Spl } \\
\text { Spl } \\
\text { Spl } \\
\text { LN } \\
\text { Spl } \\
\text { Spl } \\
\text { LN } \\
\text { Mean }\end{array}$ & $\begin{array}{l}\text { NS/MC } \\
\text { NS } \\
\text { LP } \\
\text { NS } \\
\text { NS } \\
\text { NS } \\
\text { NS } \\
\text { MC } \\
\text { NS }\end{array}$ & $\begin{array}{l}38 \% \\
0 \% \\
19 \% \\
\text { ND } \\
\text { ND } \\
\text { ND } \\
\text { ND } \\
\text { ND } \\
\text { ND } \\
19 \%\end{array}$ & $\begin{array}{l}30 \% \\
33 \% \\
10 \% \\
\text { ND } \\
\text { ND } \\
\text { ND } \\
\text { ND } \\
\text { ND } \\
\text { ND } \\
24 \%\end{array}$ & $\begin{array}{l}\text { ND } \\
45 \% \\
38 \% \\
32 \% \\
48 \% \\
50 \% \\
25 \% \\
33 \% \\
18 \% \\
36 \%\end{array}$ & $\begin{array}{c}24 \% \\
32 \% \\
23 \% \\
36 \% \\
7 \% \\
23 \% \\
\text { ND } \\
20 \% \\
\text { ND } \\
24 \%\end{array}$ & $\begin{array}{c}26 \% \\
29 \% \\
12 \% \\
38 \% \\
0 \% \\
15 \% \\
\text { ND } \\
\text { ND } \\
\text { ND } \\
20 \%\end{array}$ & $\begin{array}{c}26 \% \\
23 \% \\
14 \% \\
12 \% \\
4 \% \\
6 \% \\
\text { ND } \\
\text { ND } \\
0 \% \\
12 \%\end{array}$ & $\begin{array}{l}\text { ND } \\
\text { ND } \\
\text { ND } \\
\text { ND } \\
1 \% \\
1 \% \\
4 \% \\
0 \% \\
\text { ND } \\
1\end{array}$ \\
\hline
\end{tabular}

${ }^{*}$ Anti-Ia monoclonal, †anti-monocyte monoclonal, łanti-T cell monoclonal.

LN = lymph node, $\mathrm{Spl}=$ spleen, $\mathrm{NS}=$ nodular sclerosing, $\mathrm{MC}=$ mixed cellularity, $\mathrm{LP}=$ lymphocyte predominant, $\mathrm{ND}=$ not done.

bodies and OKM1 (Ortho Pharmaceutical Corporation) were used. OKT3 reacts with more than $95 \%$ of peripheral $\mathrm{T}$ lymphocytes and $20 \%$ of thymocytes; OKT4 reacts with $65 \%$ of peripheral T lymphocytes and $75 \%$ of thymocytes; OKT 8 reacts with $35 \%$ of peripheral $T$ lymphocytes and $80 \%$ of thymocytes; OKM1 reacts with $78 \%$ monocytes and $18 \%$ of null cells. Three anti-HLA-DR (anti-Ia) monoclonal antibodies obtained from Sera-Lab were used. These included MAS 020 and MAS 019 both antihuman B cell monomorphic DR markers, and MAS 044, an antihuman B cell polymorphic DR marker. These anti-DR monoclonal antibodies were pooled before use. In addition, two anti-Ia monoclonal antibodies, CA 206 and DA6.231, (which were the kind gift of Dr CM Steel) were used as individual reagents. The characteristics of all these monoclonal antibodies have been reported previously (see references in Table 2).

IMMUNOFLUORESCENCE

The fresh Hodgkin's disease cell suspension $(5 \times$ $10 \% / \mathrm{ml}$ ) was dispensed into $200 \mu$ l aliquots in $2 \mathrm{ml}$ capped tubes, to which was added the appropriate volume of monoclonal antibody at its optimal dilution. A normal mouse serum control was included; the dilution of the serum was such as to be equivalent to the concentration of protein in the monoclonal antibody samples. For the control with conjugate alone, a small volume of medium was added to the cell aliquot. After thorough mixing, the tubes were incubated at $4^{\circ} \mathrm{C}$ for 30 min with agitation at 10 min intervals. The cells were then washed twice in RPMI 1640 by centrifugation at $250 \mathrm{~g}$ for $7 \mathrm{~min}$ at $4^{\circ} \mathrm{C}$. The supernatants were removed, leaving about $100 \mu \mathrm{l}$ of medium and taking care to avoid dislodging the pellets. Polyvalent FITC conjugated goat (or rabbit) antimouse immunoglobulin was added to each tube as required, in $100 \mu \mathrm{l}$ aliquots, at its optimal dilution. After mixing, the cells were again incubated as before at $4^{\circ} \mathrm{C}$ for $30 \mathrm{~min}$. After two washes in medium as above, the cell pellets were resuspended in a minimum amount of medium. A drop of cell suspension was placed on a slide, covered with a coverslip, and viewed under a Leitz Ortholux II microscope equipped for phase contrast

Table 2 Summary of specifications of monoclonal antibodies

\begin{tabular}{|c|c|c|c|c|}
\hline $\begin{array}{l}\text { Monoclonal } \\
\text { antibody }\end{array}$ & Clone & Specificity & & Reference \\
\hline \multirow{2}{*}{$\begin{array}{l}\text { Anti-Ia } \\
\text { MAS } 019 \\
\text { MAS } 020 \\
\text { MAS 044 } \\
\text { CA 206 } \\
\text { DA6.231 }\end{array}$} & $\begin{array}{l}\text { S1.19/9 } \\
\text { S1.5/11 } \\
\text { E15/4 }\end{array}$ & 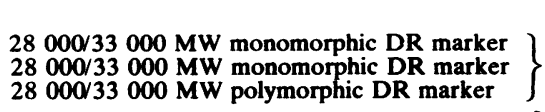 & \multirow{2}{*}{$\begin{array}{l}\text { Primary on } \\
\begin{array}{l}\text { B cells } \\
\text { B cells; activated }\end{array} \\
\begin{array}{l}\text { T cells }\end{array}\end{array}$} & Trucco et $a l^{23}$ \\
\hline & $\left.\begin{array}{ll}\cdots \\
\cdots\end{array}\right\}$ & $29000 / 34000 \mathrm{MW}$ monomorphic DR marker & & $\begin{array}{l}\text { Steel et } a l^{24} \\
\text { Guy et } a l^{25}\end{array}$ \\
\hline $\begin{array}{l}\text { Anti-T Cell } \\
\text { OKT3 }\end{array}$ & OKT3 & $\begin{array}{l}\text { Pan T cell } \\
>95 \% \text { peripheral blood T lymphocytes; } \\
20 \% \text { thymocytes; } 30 \% \text { splenocytes }\end{array}$ & & Kung et $a l^{26}$ \\
\hline OKT4 & OKT4 & $\begin{array}{l}\text { Helper inducer } \mathrm{T} \text { cell } \\
65 \% \text { peripheral blood } \mathrm{T} \text { lymphocytes; } \\
75 \% \text { thymocytes; } 15 \% \text { splenocytes }\end{array}$ & & Reinherz et $a l^{27} 28$ \\
\hline OKT8 & OKT8A & $\begin{array}{l}\text { Suppressor/cytotoxic T cell } \\
35 \% \text { peripheral blood T lymphocytes; } \\
80 \% \text { thymocytes; } 15 \% \text { splenocytes }\end{array}$ & & Reinherz et $a l^{29} 30$ \\
\hline \multicolumn{2}{|c|}{$\begin{array}{l}\text { Anti-monocyte/null cell/granulocyte } \\
\text { OKM1 }\end{array}$} & $78 \%$ monocytes; $18 \%$ null cells & & Breard et $a l^{31}$ \\
\hline
\end{tabular}

Anti-monocyte/null cell/granulocyte 
and fluorescent microscopy. Occasionally, if it was not possible to count all the suspensions immediately, the cell pellets were finally resuspended in $1 \%$ formaldehyde in phosphate buffered saline, which preserved both the cells and the fluorescence for up to a week. ${ }^{12}$ All samples were initially examined under phase contrast to identify the Reed-Sternberg cells with their rosette of lymphocytes. Each ReedSternberg cell rosette was then examined under the fluorescence objective.

\section{Results}

The number of rosetted lymphocytes reactive with each monoclonal antibody was expressed as a percentage of the total number of rosetting cells in a given sample, as shown in Table 1. Earlier studies with heterologous anti-T cell serum confirmed that most of the rosetting lymphocytes were $T$ cells. The monoclonal anti- $T$ cell sera revealed two major subsets-namely, helper and suppressor $T$ cells. Most of the rosetting lymphocytes that were reactive with the OKT series of monoclonal antibodies were either OKT3 (pan T cell) or OKT4 (helper/inducer $T$ cell) positive. In some Hodgkin's disease cases, however, there were equal numbers of OKT4 and OKT8 (suppressor/cytotoxic) positive cells. Overall, there was a higher proportion of helper $\mathrm{T}$ cells than suppressors among the rosetting lymphocytes. On average, only $1 \%$ of the rosetted lymphocytes were OKM1 positive and were therefore presumably null cells. Null cells would also account for some of the $\mathrm{Ia}^{+}$rosetted cells.

A small percentage (10-20\%) of rosetting lymphocytes were seen to react with the heterologous anti-B sera or were $\mathrm{S}_{\mathrm{Ig}^{+}}$. Furthermore, on average $19-36 \%$ of the rosetting lymphocytes were positive with the monoclonal anti-Ia sera. These percentages would include not only B lymphocytes but also any activated $T$ cells which are known to bear Ia antigens. Unfortunately, it was not possible to carry out double labelling experiments with the monoclonal antibodies so as to determine what proportion of $T$ cells were $\mathrm{Ia}^{+}$.

\section{Discussion}

Our study on the Reed-Sternberg cell/lymphocyte rosette was carried out on fresh viable cell suspensions prepared from Hodgkin's disease tissue, because these enabled more accurate assessment of the numbers of rosettes and of the number and nature of the adherent cells. A preliminary examination of cryostat sections indicated that these were inadequate for accurate quantitative asessment of the numbers of rosetting lymphocytes around
Reed-Sternberg cells, as the overall picture was obscured by underlying cells. While there is the danger of artefactual rosetting occurring when cell suspensions are prepared, we are confident that the rosettes we obtained were true rosettes, representative of the in vivo situation. These rosettes exhibited firm binding and were not readily broken up by the multiple manipulations and washing of the immunofluorescence technique. In addition, it was considerably easier to identify the Reed-Sternberg cells under phase contrast as they were quite distinct in suspension (see Figure), unlike cryostat sections, which are not easily visualised under these conditions. Furthermore, the suspension technique permitted the use of washed cells with a living and intact surface membrane, giving a much greater area for antigen detection than is available with sectioned material. Dead or dying cells rarely survived the washing process, thus diminishing the likelihood of anomalous results due to adsorption of extraneous material or the passive infiltration of enzymes or plasma proteins through an excessively permeable cell membrane. It is for these reasons that we preferred to use the suspension technique. While it would have been ideal to have done immunoperoxidase studies in parallel, there was insufficient material to allow for this.

Since OKT and other anti-T cell monoclonal antibodies became available there has been renewed interest in the $\mathrm{T}$ cell subpopulations in peripheral blood, ${ }^{12}$ spleen, and lymph nodes in Hodgkin's disease. Dorreen et $\mathrm{l}^{13}$ reported that the predominant $\mathrm{T}$ cell type in Hodgkin's disease lymph nodes and spleens was the helper/inducer $\mathrm{T}$ cell, as defined by monoclonal antibodies. It is therefore not surprising that our results also showed that most rosetting $T$ lymphocytes around Reed-Sternberg cells were of the helper subset. Aisenberg and Wilkes ${ }^{14}$ also noted the preponderance of helper/inducer $\left(\mathrm{OKT}^{+}\right) \mathrm{T}$ cells in Hodgkin's disease lymph nodes. They suggested that the binding of $T$ cells to ReedSternberg cells may be due to altered surface mem-

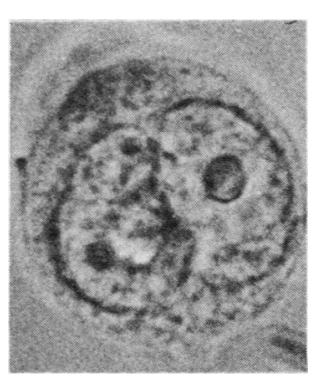

Reed-Sternberg cell in suspension visualised by phase contrast. $\times 400$ 
brane properties of T lymphocytes in Hodgkin's disease. Poppema et $a^{15}$ also extensively examined Hodgkin's disease lymph node and spleen frozen sections with the OKT series of monoclonal antibodies and OKI1. Their observations on the overall $T$ cell populations were in agreement with those mentioned above. They also found that the $\mathrm{T}$ cells surrounding Reed-Sternberg cells were predomi-

$\mathrm{OKT}^{+}, \mathrm{T}^{+}$, and $\mathrm{T}^{+}$, but were $\mathrm{T}^{-}$. These results are in keeping with our results, although we also found a proportion of rosetting $\mathrm{OKT} 8^{+}$cells.

In an earlier study Payne et al ${ }^{16}$ examined the rosetting $T$ cells in an attempt to classify their subtype and to define the nature of the Reed-Sternberg cell/lymphocyte interaction. They concluded that most of the rosetting T cells lacked Fc $\gamma$ (suppressor $\mathrm{T}$ ) or $\mathrm{Fc} \mu$ (helper $\mathrm{T})$ receptors but a few (5-15\%) had one or the other receptor. Our results confirmed that the majority of rosetting cells were $T$ cells when heterologous anti- $T$ cell serum was used. The monoclonal anti- $T$ sera revealed two major subsetsnamely, helper and suppressor $T$ cells. Our results differ from those of Payne et al in that there was a higher proportion of helper than suppressor $T$ cells involved in the lymphocyte/Reed-Sternberg cell rosettes. No strict correlation is possible between our results and those of Payne et al, since the $T$ cell subsets defined by $F c$ receptors and those defined by the OKT monoclonal antibodies are not identical. ${ }^{17}$ Since only $12 \%$ of rosetting T cells were $\mathrm{OKT} 8^{+}$, it would seem unlikely that these cells were mounting a cytotoxic response. Payne et al, in their more extensive study, could find no evidence of such a response.

Borowitz et al ${ }^{18}$ also noted that the predominant $\mathrm{T}$ cell around the Reed-Sternberg cells was of the helper subset, and their conclusion was in agreement with ours-namely, that the T cells were not mounting a cytotoxic response. They observed that in lymphocyte depleted Hodgkin's disease suppressor T cells were often associated with Reed-Sternberg cells, but this observation was based on low numbers of Reed-Sternberg cell/T cell rosettes actually counted. Of major interest was the observation by Borowitz et al that many $\mathrm{T}$ cells around ReedSternberg cells were positive with a monoclonal antibody specific for the transferrin receptor, thus indicating that these were activated lymphocytes. This is in agreement with our results with the anti-Ia monoclonal antibodies, which revealed a surprisingly high number of $\mathrm{Ia}^{+}$lymphocytes around the Reed-Sternberg cells. Activated T cells are known to bear Ia antigens, and the percentage (19-36\%) of $\mathrm{Ia}^{+}$lymphocytes that we observed was in excess of that which could be accounted for by those lymphocytes reactive with heterologous anti-B serum (10-
$20 \%$ ) and other lymphocytes, presumably null cells, reactive with OKM1 $(1 \%)$. We are confident that the small mononuclear cells positive with OKM1 were correctly identified under phase contrast and were not monocytes, which are clearly distinguishable and rarely found around Reed-Sternberg cells. Borowitz et al also referred to an excess of $\mathrm{Ia}^{+}$cells, which could not be accounted for by $B$ cell numbers alone and which they took to be activated $\mathrm{T}$ cells.

Our results clearly indicated a proportion of $B$ cells around Reed-Sternberg cells. Apart from the report by Curran and Jones," who observed ReedSternberg cells associated with both $\mathrm{S} \mathrm{Ig}^{-}$and $\mathrm{S} \mathrm{Ig}^{+}$ cells, we have found no other reference to $B$ cells in the Reed-Sternberg cell/lymphocyte rosette. Poppema et al $^{1920}$ reported that in lymphocyte predominant Hodgkin's disease of the nodular paragranuloma type Reed-Sternberg cells were located primarily in B cell areas of lymph nodes. Our finding of a few B cells around Reed-Sternberg cells was irrespective of Hodgkin's disease subtype.

It is apparent that the nature and importance of the Reed-Sternberg cell/lymphocyte rosette depends on both the nature of the Reed-Sternberg cell itself and that of the surrounding lymphocytes. The inquisitive and aggressively motile interaction of lymphocytes with the Reed Sternberg cell is unique and to our knowledge has not been noted in any other cell to cell interactions. The interaction of lymphocytes with the Reed-Sternberg cell is reminiscent of similar interactions between macrophages and lymphocytes. In previous studies ${ }^{\mathrm{B}} 11$ we investigated the antigenic character of the ReedSternberg cell with a range of heterologous and monoclonal antisera and found no evidence of monocyte/macrophage antigens being present on Reed-Sternberg cells. These studies clearly showed that Reed-Sternberg cells had antigens in common with B cells. This has now been confirmed in a more recent publication. ${ }^{21}$ The rosetting of $\mathrm{T}$ lymphocytes around B lymphoblastoid cells is well recognised and may be analogous to the Reed-Sternberg cell/ lymphocyte rosettes. If this is so it seems to us that the Reed-Sternberg cell could be a blast cell which operates late in the immune response and evades modulation by physiological influences which normally control the efferent lymphoid response. The role of the helper $\mathrm{T}$ cells in this interaction may be the key to our understanding of this rosetting phenomenon.

Payne $e t$ al, ${ }^{10}$ in their careful study of this interaction, considered that it resembled antigen independent lymphocyte-macrophage binding. Owing to the unique physiological requirements of the Reed-Sternberg cell/lymphocyte interaction they proposed that a unique receptor system was 
involved.

In their brief study, McGuire et $^{2} \mathrm{l}^{22}$ considered the Reed-Sternberg cell/lymphocyte rosette as a possible prognostic indicator. They found that the disease had a more favourable prognosis in patients who had a high proportion of Reed-Sternberg cell/ lymphocyte rosettes, as evaluated retrospectively. It would require a much larger study than ours and over a longer period in order to correlate any changes in the percentage of Reed-Sternberg cell/ lymphocyte rosettes and the nature of the attached lymphocytes during the course of the disease in those patients undergoing a relapse from whom subsequent biopsies might be obtained. These factors also need to be correlated with any change in Hodgkin's disease subtype. As indicated by one case mentioned in the report by Borowitz et al ${ }^{18}$ it is possible that an increase in suppressor $T$ cells around ReedSternberg cells may lead to a more benign progression of the disease. An understanding of the role of the Reed-Sternberg cell/lymphocyte interaction in Hodgkin's disease could lead to ways of manipulating the response to improve prognosis.

\section{References}

' Dorfman RF, Rice DF, Mitchell AD, Kempson RL. Ultrastructural studies of Hodgkin's Disease. Natl Cancer Inst Monogr 1973; 36:221-38.

${ }^{2}$ Archibald RB, Frenster JH. Quantitative ultrastructural analysis of in vivo lymphocyte-Reed-Sternberg cell interactions in Hodgkin's Disease. Natl Cancer Inst Monogr 1973;36:239-45.

${ }^{3}$ Frenser JH, Papallan NM, Masek MA, Frenster JA. Electron microscopic analysis of lymph node cellular activity in Hodgkin's Disease. J Natl Cancer Inst 1979;63:331-5.

+ Kadin ME, Newcom SR, Gold SB, Stites DP. Origin of Hodgkin s cell. Lancet 1974 ;ii: 167-8.

'Braylan RC, Jaffe ES, Berard CW. Surface characteristics of Hodgkin's lymphoma cells. Lancet 1974; ii: 1328-9.

'Payne SV, Jones DB, Wright DH. Reed-Sternberg-cell lymphocyte interaction. Lancet 1977; ii: 768.

' Stuart AE, Williams ARW, Habeshaw JA. Rosetting and other reactions of the Reed-Sternberg cell. J Pathol 1977;122:8190.

${ }^{*}$ Morris CS. The use of cell-specific antisera and lectins to analyse the nature of the Reed-Sternberg cell of Hodgkin's Disease. Newcastle upon Tyne: University of Newcastle upon Tyne 1983. PhD Thesis.

" Curran RC, Jones EL. Dendritic cells and B lymphocytes in Hodgkin's Disease. Lancet 1977;ii: 349.

1" Stuart AE, Dewar AE. Properties of anti-hairy cell serum. Br J Haematol 1979;41:163-8.

"Stuart AE, Jackson E, Morris CS. The reaction of xenogeneic and monoclonal antisera with Reed-Sternberg cells. J Pathol 1982;137:129-38.

12 Posner MR, Reinherz EL, Breard J, Nadler LM, Rosenthal DS, Schlossman SF. Lymphid subpopulations of peripheral blood and spleen in untreated Hodgkin's Disease. Cancer 1981;48: 1170-6.

${ }^{13}$ Dorreen MS, Habeshaw JA, Wrigley PFM, Lister TA. Distribution of T-lymphocyte subsets in Hodgkin's Disease characterized by monoclonal antibodies. Br J Cancer 1982;45:491-9.

it Aisenberg AC, Wilkes BM. Lymph node T cells in Hodgkin's
Disease: Analysis of suspensions with monoclonal antibody and rosetting techniques. Blood 1982;59:522-7.

15 Poppema S, Bhan AK, Reinherz EL, Posner MR, Schlossman SF. In situ immunologic characterization of cellular constituents in lymph nodes and spleens involved by Hodgkin's Disease. Blood 1982;59:226-32.

${ }^{16}$ Payne SV, Newell DG, Jones DB, Wright DH. The ReedSternberg cell/lymphocyte interaction. Ultrastructure and characteristics of binding. Am J Pathol 1980; 100: 7-24

${ }^{17}$ Reinherz EL, Moretta L, Roper M, et al. Human T lymphocyte subpopulations defined by Fc receptors and monoclonal antibodies. A comparison. J Exp Med 1980;151:969-74.

${ }^{1 *}$ Borowitz MJ, Croker BP. Metzgar RS. Immunohistochemical analysis of the distribution of lymphocyte subpopulations in Hodgkin's disease. Cancer Treat Rep 1982;66:667-74.

${ }^{14}$ Poppema S, Kaiserling E, Lennert K. Nodular paragranuloma and progressively transformed germinal centers. Virchows Archiv B (Cell Pathol) 1979;31:211-25.

2" Poppema S, Kaiserling E, Lennert K. Hodgkin's disease with lymphocytic predominance, nodular type (nodular paragranuloma) and progressively transformed germinal centres:a cytohistological study. Histopathology 1979;3:295-308.

"Stuart AE. Volsen SG. Zola H. The reactivity of Reed-Sternberg cells with monoclonal antisera at thin section and ultrastructural levels. J Pathol 1983;141:71-82.

22 McGuire RA, Pretlow TG. Wareing TH, Bradley EL. Hodgkin's cells and attached lymphocytes. A possible prognostic indicator in splenic tumor. Cancer 1979;44: 183-7.

${ }^{23}$ Trucco MM, Garotta G, Stocker JW, Cepellini R. Murine monoclonal antibodies against HLA structures. Immunol Rev 1979;47;219-52.

${ }^{24}$ Steel CM, Van Heyningen V, Guy K, et al. Monoclonal anti-B cell antibodies: their effects on human mixed lymphocyte reactions. In: Peeters H, ed. Protides of the biological ftuids. (29th Colloquium 1981). Oxford and New York: Pergamon Press, 1982:695-9.

2s Guy K, Van Heyningen V, Cohen BB, Dean DL, Crichton D, Steel CM. Subsets of human D locus products identified by a series of monoclonal antibodies. In: Peeters H, ed. Protides of the biological fuids. (29th Colloquium 1981). Oxford and New York: Pergamon Press, 1982:729-34.

${ }^{20}$ Kung PC, Goldstein G, Reinherz EL, Schlossman SF. Monoclonal antibodies defining distinctive human $T$ cell surface antigens. Science 1979; 206:347-9.

${ }^{27}$ Reinherz EL, Kung PC, Goldstein G, Schlossman SF. Separation of functional subsets of human $\mathrm{T}$ cells by a monoclonal antibody. Proc Natl Acad Sci USA 1979;76:4061-5.

2* Reinherz EL, King PC, Goldstein G, Schlossman SF. Further characterization of the human inducer $T$ cell subset defined by monoclonal antibody. J Immunol 1979; 123:2894-6.

${ }^{24}$ Reinherz EL, Kung PC, Pesando JM, Ritz J, Goldstein G, Schlossman SF. Ia determinants on human T-cell subsets defined by monoclonal antibody. J Exp Med 1979;150:147282.

3" Reinherz EL, Kung PC, Goldstein G, Levey RH, Schlossman SF. Discrete stages of human intrathymic differentiation: Analysis of normal thymocytes and leukemic lymphoblasts of T-cell lineage. Proc Natl Acad Sci USA 1980;77:1588-92.

${ }^{31}$ Breard J, Reinherz EL, Kung PC, Goldstein G, Schlossman SF. A monoclonal antibody reactive with human peripheral blood monocytes. J Immunol 1980; 124: 1943-8.

Requests for reprints to: Dr C S Morris, Department of Neurosurgery, The Midland Centre for Neurosurgery and Neurology, Holly Lane, Smethwick, Warley, West Midlands B67 $7 \mathrm{JX}$. 